$\begin{array}{ll}\text { Volume } & : 7 \\ \text { Nomor } & : 3 \\ \text { Bulan } & : \text { Agustus } \\ \text { Tahun } & : 2021\end{array}$

\title{
EKSITENSI Hukum Cambuk (Mihita La Ua Uatto) dalam Masyarakat Adat Iha-Ulupia Dikaji dalam Prespektif Hak Asasi Manusia (HAM)
}

\author{
Muhammad Luhulima \\ Fricean Tutuarima \\ Aisa Abas \\ Universitas Pattimura, Ambon, Indonesia \\ Pos-el: muhammadluhulima12@gmail.com
}

DOI: 10.32884/ideas.v7i3.452

\begin{abstract}
Abstrak
Penelitian ini bertujuan untuk mendeskripsikan eksitensi hukum cambuk (mihita la ua uatto) dalam masyarakat adat Iha-Ulupia dikaji dalam prespektif Hak Asasi Manusia (HAM). Penelitian ini menggunakan deskriptif kualitatif yang bertujuan untuk mengetahui pelaksanaan hukum cambuk dan pandangan Hak Asasi Manusia terhadap pelaksanaan hukum cambuk. Teknik pengambilan data primer dilakukan melalui observasi, wawancara, dan dokumentasi terhadap sejumlah informan yang dianggap terlibat secara langsung dalam proses pelaksanaan hukum cambuk (mihitta la ua uatto). Hasil penelitian ini menunjukan bahwa eksitensi hukum cambuk (mihita la иа иatto) dalam masyarakat adat Iha-Ulupia di kaji dalam prespektif Hak Asasi Manusia (HAM) di negeri IhaUlupia Kecamatan Huamual, Kabupaten Seram Bagian Barat terlaksana dengan baik. Hukum cabuk yang diterapkan di negeri Iha-Ulupia masih bersumber pada salah satu sumber hukum yang masih berlaku di Indonesia yaitu hukum adat, hukum cambuk yang diterapkan di negeri iha-ulupia secara substansi tidak melanggar hukum positif dalam hal ini UU HAM karena memiliki landasan pada pasal 18 b ayat (2) UUD 1945.
\end{abstract}

\section{Kata Kunci}

eksitensi, hukum cambuk, hak asasi manusia (HAM)

\begin{abstract}
This study aims to describe the existence of the Caning Law (Mihia La Ua Uatto) in the Iha-Ulupia Indigenous Peoples Study in the Perspective of Human Rights (HAM). Asai Man against the implementation of the caning law. The primary data collection technique was carried out through observation, interviews, and documentation of a number of informants who were considered to be directly involved in the process of implementing the caning law (mihitta la ua uatto). The results of this study indicate that the existence of the law of whips (Mihita La Ua Uatto) in the Tha Ulupia Indigenous Peoples is studied in the perspective of human rights (HAM) in Iha-Ulupia Country, Huamual District, West Seram Regency. Iha-ulupia country is still based on one of the legal sources that are still valid in Indonesia, namely customary law, the caning law applied in Iha-ulupia country substantially does not violate positive law in this case the Human Rights Law because it has a basis in article 18 b paragraph (2) 1945 Constitution
\end{abstract}

Keywords

existence, caning law, human rights (HAM)

\section{Pendahuluan}

Bangsa Indonesia adalah suatu bangsa yang dianugerahi Tuhan yang Maha Esa, Allah Swt., yang memiliki beraneka ragam adat dan kebudayaan yang tersebar di seluruh pelosok tanah air yang didiami begitu banyak suku bangsa. Keanekaragam ini bukanlah sesuatu yang dipertentangkan, melainkan sesuatu kekayaan budaya yang patut dijaga dan dilestarikan serta dimanfaatkan bagi kesejahteraan bangsa Indonesia. Di Indonesia berbagai macam budaya yang diterapkan di masing-masing daerah dengan berbagai perbedaan budaya yang ada, sebagaimana dikutip dalam jurnal (Ona Yulita, Khairul Anwar, Dody Putra, 2021) untuk melihat tujuan utama dalam kebudayaan, maka dibuktikan bahwa sekumpulan manusia serta karakteristik demografisnya masingmasing. Tetapi sebagai manusia seperti biasanya yang memiliki kebudayaan atau adat tradisi sendiri, termasuk sistem norma dan sosial terkhusus Provinsi Maluku. 
Eksistensi masyarakat hukum adat merupakan suatu kenyataan sejarah yang tidak dapat dipisahkan oleh pemerintah. Masyarakat adat tidak dapat dilepaskan dari pengertian masyarakat hukum adat bahwa masyarakat hukum adat adalah kesatuan kemasyarakatan yang mempunyai kelengkapan-kelengkapan untuk sanggup berdiri sendiri yaitu mempunyai kesatuan hukum, kesatuan penguasa dan kesatuan lingkungan (Malady,2010).

Masyarakat hukum adat sudah diakomudir oleh konstitusi negara dalam kaitannya dengan hak asasi manusia. Hal ini karena hak-hak yang dimiliki manusia itu adalah semata-mata karena ia adalah manusia. Umat manusia memilikinya bukan karena diberikan kepadanya oleh masyarakat atau berdasarkan hukum positif, tetapi semata-mata berdasarkan martabatnya sebagai manusia, meskipun setiap orang terlahir dengan ras, suku, jenis kelamin, bahasa, budaya, agama dan kewarganegaraan yang berbeda-beda, ia tetap mempunyai hak-hak yang harus dijunjung tinggi oleh siapapun juga, dan di negara manapun ia berada. Inilah sifat universal dari HAM tersebut (Sumanto, 2018).

Mengenal ciri khas sosial budaya di daerah Maluku khususnya di Negeri Iha-Ulupia Kecamatan Huamual, Kabupaten seram Bagian Barat, tentunya tidak dapat dipisahkan dari berbagai pranata adat yang yang ada pada suatu komonitas atau daerah tertentu. salah satu budaya yang di terapkan pada masyarakat adat Iha-Ulupia sampai pada saat ini yakni Hukum Cambuk (Mihita La Ua Uatto) seperti yang di kutip dalam jurnal (Nurdianzah, Erry, 2020) dalam kutipannya budaya mengandung pengertian yang luas, meliputi pemahaman perasaan suatu bangsa yang kompleks, meliputi pengetahuan, kepercayaan, seni, moral, hukum, adat istiadat dan pembawaan lain yang diperoleh dari masyarakat.

Negeri Iha merupakan salah satu wilayah di Kecamatan Huamual Kabupaten Seram Bagian Barat yang terletak pada posisi 20 55’00 - 30 02’00 Lintang Selatan dan 1200 00’00 - 1200 09’00 Bujur Timur. Secara geografis Negeri iha terletak di sebelah Selatan Pulau Seram, dimana Negeri ini berada di pesisir pantai timur dengan memiliki batas-batas wilayah dengan kecamatan lainnya sebagai berikut; sebelah utara berbatasan dengan dengan kecamatan taniwel, sebelah selatan berbatasan dengan kecamatan leihitu dan laut banda, sebelah timur berbatasan dengan kecamatan Kairatu, sebelah barat berbatasan dengan selat manipa. Selain itu Negeri Iha secara Nasional terdapat 2 Desa di dalamnya yaitu Desa Iha dan Desa Kulur tetapi secara adat hanya terdapat satu Negeri yaitu Negeri Iha dengan nama Adat Noraito Amalatu atau biasa dikenal dengan sebutan Ama Iha Ulu Pia. Negeri Iha juga mempunyai hubungan gandong adik-kakak dengan Negeri Iha Mahu di kecamatan Saparua Kabupaten Maluku Tengah dengan nama adat Noraito Ama Patti.

Eksitensi Hukum Cambuk (Mihitta la иа иatto) pertama kali di lakukan di Negeri Iha-Ulupia sejak tahun 1990-an di bawa pimpinan raja Abdul Gawi Latukaisupy dan masih berlaku hingga sekarang ini, aturan ini merupakan salah suatu budaya yang di berikan oleh leluhur kepada masyarakat adat Iha-Ulupia dengan tujuan terhindar dari berbagai musibah yang terjadi di Negeri Iha-Ulupia. Hukum adat yang bisa di katakan kuno dan unik yang mungkin untuk zaman yang sudah modern ini tidak di temukan lagi di bumi raja-raja di Maluku yaitu Hukum Cambuk (mihita la ua uatto).

Hukuman ini atas dasar kesepakatan masyarakat adat Iha-Ulupia secara kolektif untuk melindungi berbagai perilaku penyimpangan sosial, seperti minuman keras, pencurian, perjudian, perzinahan. Tetapi dengan perubahan zaman, hukuman cambuk ini sudah tidak berlaku lagi untuk perzinahan, pencurian, perjudian. Karena sampai sekarang ini masyarakat adat Iha-Ulupia tidak melakukan ke-tiga hal tersebut. Hukuman cambuk sampai saat ini hanya berlaku untuk minuman keras, di karenakan cikal bakal kejahatan masyarakat khususnya pemudapemuda timbul dari minuman keras, untuk itu, dengan adanya di terapkan hukuman cambuk di Negeri IhaUlupia ini agar terhindar dari berbagai malapetaka (musibah) yang terjadi pada masyarakat adat, dan guna mengatur kehidupan masyarakat menuju keharmonisan sosial kultural di dalam kehidupan masyarakat adat di Negeri Iha-Ulupia dengan begitu seluruh anggota masyarakat yang ada di Negeri Iha-Ulupia bisa hidup aman, tentram dan damai. Untuk itu hukum adat cambuk (mihita la иa uatto) ini tetap di jaga dan di lestarikan sampai pada generasi-generasi Ih-Ulupia ke depan, sama halnya yang di kutip dalam jurnal (Latupapua, F. E. 2009) meskipun nilai-nilai budaya yang bersifat historis genealogis di antara mereka pun masih tetap diakui dan dijaga, terdapat banyak perbedaan penafsiran secara individual di antara anggota masyarakat dalam kaitan dengan sejarah dan hubungannya dengan pluralitas masyarakatnya (Tutuarima, dkk, 2009).

Hukum Cambuk (Mihita La Ua Uatto) menjadi salah satu sanksi hukum adat, relative menjadi deferensiasi sosial (pengendali sosial) bagi kehidupan masyarakat, iya hukum cambuk sedikitnya mampu menurunkan tingkat pelanggaran. ada efek jerah bukan hanya di rasakan oleh si pelaku penerima hukuman, namun bisa menjadi contoh bagi masyarakat lainnya. 


$\begin{array}{ll}\text { Volume } & : 7 \\ \text { Nomor } & : 3 \\ \text { Bulan } & : \text { Agustus } \\ \text { Tahun } & : 2021\end{array}$

Hukum cambuk yang di terapkan di Negeri Iha-Ulupia sampai sekarang masih bertahan, hukum ini tidak bisa di hilangkan begitu saja, karena aturan ini dari leluhur kita, kalau aturan hukum cambuk ini di hentikan, sudah pastinya Negeri kita akan mengalami suatu musiba, dan banyak generasi membuat Negeri ini akan kotor, narkoba dimana-mana, minuman keras dimana-mana, dan hukum ini. dengan adanya hukum cambuk (mihitta la иа иаtto) ini masyrakat di Negeri Iha-Ulupia menginginkan terciptanya masyarakat yang tertib. Ketertiban itu sendiri merupakan nilai yang bersifat normatif, dimana ketertiban merupakan sesuatu yang diinginkan atau dicita-citakan oleh setiap manusia dalam kehidupan bermasyarakat dalam menjaga tatanan adat. Dan secara substansi hukuman cambuk ini tidak melanggar Hak Asasi Manusia (HAM) karena memiliki landasan pada pasal 18 B ayat (2) UUD. Dan KUHP benar tertulis mengenai perkara pidana di Indonesia namun tidak mengsampingkan hukum adat yang berlakukan pada wilayah yang ada di Indonesia. kemudian secara regulasi dia merupakan sumber hukum yang masih berlaku diindonesia yang di akui secara tidak tertulis untuk mengatur ketertiban masyarakat, jadi aturan ini tidak boleh di hilangkan, harus tetap di pertahankan sampai generasi berikutnya.

Di satu sisi, hukum cambuk (mihita la ua uatto) yang di terapkan di Negeri Iha-Ulupia merupakan budaya masyarakat adat Iha-Ulupia, tetapi dengan adanya perkembangan zaman, sudah berlakunya konstitusi negara yakni Undang-Undang yang berlaku di Negara Republik Indonesia, bagimana nantinya hukum cambuk ini akan di protes oleh oknum-oknum tertentu, hal ini tentu menjadi sebuah permasalahan hukum adat yang terjadi di negeri iha-ulupia. dengan rumusan masalah bagaimana pelaksanaan hukum cambuk (mihita la ua uatto) di Negeri Iha-Ulupia, dan bagaiman pandangan hak asasi manusia (ham) terhadap pelaksanaan hukum cambuk (mihita la ua uatto) di Negeri Iha-Ulupia. kemudian di paparkan secara umum, tujuan dari penelitian ini adalah untuk mengetahui bagaimana pelaksanaan hukum cambuk di Negeri Iha-Ulupia, dan mengetahui bagaimana Pandangan Hak Asasi Manusia (HAM) terhadap pelaksanaan hukum cambuk di Negeri Iha-Ulupia.

\section{Metode}

Penelitian ini menggunakan pendekatan kualitatif. Pendekatan kualitatif adalah pendekatan untuk membangun pernyataan pengetahuan berdasarkan persfektif-konstruktif misalnya, makna-makna yang bersumber dari pengalaman individu, nilai-nilai sosial dan sejarah, dengan tujuan untuk membangun teori atau pola pengetahuan tertentu atau berdasarkan presfektif partisipatori (Creswell, 2016).

Teknik pengumpulan data yang peneliti gunakan di antaranya: Observasi: yang dimana observasib dilakukan secara sengaja dan langsung ke objek yang diteliti agar dapat memperoleh gambaran yang sebenarnya terhadap permasalahan yang diteliti (Sugiyono, 2014), kemudian wawancara: peneliti melakukan penelitian dengan melakukan wawancara. Metode wawancara dapat di katakan sebagai bteknik pengumpulan data apabila penelitian melakukan studi untuk menemukan permasalahan yang harus di teliti dan ingin mengetahui hal-hal dan responden yang lebih mendalam (Sugiyono, 2014), dan juga Dokumentasi yang digunakan dalam penelitia ini dengan tujuan untuk memperjelas kebahasaan data atau pendukung data yang di peroleh.

Teknik analisis data yang harus peneliti gunakan yaitu teknik analisis data model interaktif dari Miles dan Huberman ini memiliki tiga tahapan, yaitu Reduksi data, Penyajian data, dan Penarikan kesimpulan. Analisis data dengan model interaksi dari Miles dan Huberman dapat digambarkan sebagai berikut (Burhan bungin, 2010). Reduksi Data (data reduction) merupakan proses selesksi, pemfokusan, penyerhanaan, dan abstraksi. Sedangkan Penyajian data adalah kumpulan informasi yang tersusun sehingga dapat memberikan penarikan kesimpulan dan pengambilan tindakan lebih lanjut. Dan Penarikan Kesimpulan (conclusion) Penarikan kesimpulan merupakan langkah terakhir dalam pembuatan suatu laporan penelitian.

\section{Hasil dan Pembahasan \\ Hasil \\ Pelaksanaan Hukum Cambuk (Mi Hita La Ua Uatto) di Negeri Iha-Ulupia}

Eksitensi Hukum Cambuk (Mihitta la ua uatto) pertama kali di lakukan di Negeri Iha-Ulupia sejak tahun 1990an di bawa pimpinan raja Abdul Gawi Latukaisupy dan masih berlaku hingga sekarang ini, aturan ini merupakan salah suatu budaya yang di berikan oleh leluhur kepada masyarakat adat Iha-Ulupia dengan tujuan terhindar dari berbagai musibah yang terjadi di Negeri Iha-Ulupia. Hukum adat yang bisa di katakan kuno dan unik yang mungkin untuk zaman yang sudah modern ini tidak di temukan lagi di bumi raja-raja di Maluku yaitu Hukum

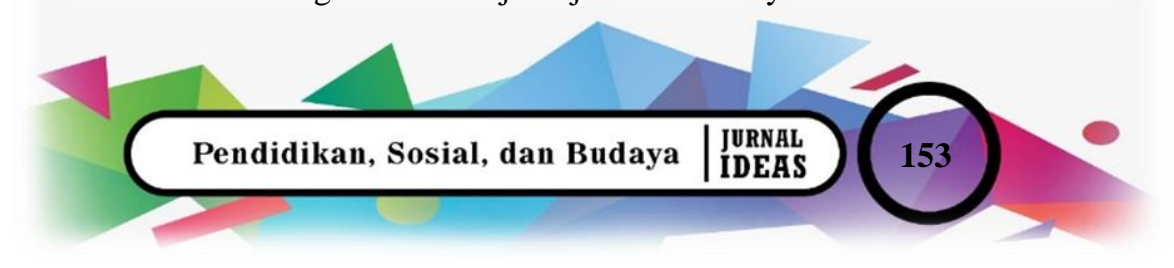


Cambuk (mihita la ua uatto).

Hukuman ini atas dasar kesepakatan masyarakat adat Iha-Ulupia secara kolektif untuk melindungi berbagai perilaku penyimpangan sosial, seperti minuman keras, pencurian, perjudian, perzinahan. Tetapi dengan perubahan zaman, hukuman cambuk ini sudah tidak berlaku lagi untuk perzinahan, pencurian, perjudian. Karena sampai sekarang ini masyarakat adat Iha-Ulupia tidak melakukan ke-tiga hal tersebut. Hukuman cambuk sampai saat ini hanya berlaku untuk minuman keras, di karenakan cikal bakal kejahatan masyarakat khususnya pemudapemuda timbul dari minuman keras, untuk itu, dengan adanya di terapkan hukuman cambuk di Negeri IhaUlupia ini agar terhindar dari berbagai malapetaka (musibah) yang terjadi pada masyarakat adat, dan guna mengatur kehidupan masyarakat menuju keharmonisan sosial kultural di dalam kehidupan masyarakat adat di Negeri Iha-Ulupia dengan begitu seluruh anggota masyarakat yang ada di Negeri Iha-Ulupia dapat hidup dengan tentram dan damai. dimana hukum cambuk menjadi salah satu sanksi hukum adat, relative menjadi deferensiasi sosial (pengendali sosial) bagi kehidupan masyarakat, iya hukum cambuk sedikitnya mampu menurunkan tingkat pelanggaran. ada efek jerah bukan hanya di rasakan oleh si pelaku penerima hukuman, namun bisa menjadi contoh bagi masyarakat lainnya.

Berbicara persoalan pelaksanaan Hukum cambuk (mihitta la ua uatto) sebenarnya jika disaksikan langsung oleh orang-orang yang belum pernah melihatnya maka ia akan merasa aneh bahkan takut untuk menyaksikan proses hukum cambuk tersebut sebab hukum cambuk ini di lakukan dengan cara memukul badan seseorang yang sudah di buka bajunya sehingga yang di lihat hanyalah kulit badannya dan di pukul dengan rotan jawa yang berukuran satu meter dengan panjang dan tebalnya $25 \mathrm{~cm}$. Sedemikian sehingga apabila mengenai badan seseorang langsung kulitnya pecah dan bahkan keluar percikan darah di bagian belakang orang yang dicambuk sehingga apabila ada orang baru yang ingin menyaksikan proses hukum cambuk ini bisa takut bahkan histeris karena sangat ekstrim dan badan orang yang dicambuk juga tidak di berikan berkat atau mantra-mantra yang biasanya diberikan agar kebal terhadap cambukkan rotan jawa tersebut. Untuk melihat prosesi hukam cambuk yang di terapkan di negeri iha-ulupia sebagai barikut;

Hukuman cambuk (mihitta la ua uatto) ini bertujuan untuk menjaga ketertiban dan kesucian di dalam masyarakat adat Iha-Uluia dari berbagai jenis mala-petaka (musibah) yang terajdi pada masyarakat adat IhaUlupia.

"Hukum cambuk (mihitta la ua uatto) ini jua sebagai simbolisasi dari pada adat istiadat yang su ada dari dolo par kasi efek jera untuk orang-orang yang langgar aturan adat jadi sapa yang langgar aturan adat in, harus terima resikonya seng boleh barmaeng maeng deng akang Karena katong su jalani akang dari dolo makanya hukum cambuk ini juga warisan adat istiadat dari pada leluhur par ana cucu.”

"Hukum cambuk (mihitta la ua uatto) ini merupakan simbolisasi adat-istiadat yang sudah di berlakukan sejak lama untuk memberikan efek jera kepada masyarakat yang melakukan pelanggaran aturan adat, siapa yang melanggar aturan adat ini, harus menerima hukuman, dan tidak boleh anggap remeh terkait aturan hukum cambuk ini."

Dari penjelasan di atas dianalisis bahwa adat hukum cambuk (mihitta la ua uatto) merupakan sebuah bentuk tradisi yang dipraktekan dalam kehidupan masyarakat untuk pelanggar-pelanggar seperti yang telah di sebutkan diatas dan tradisi hukum cambuk (mihitta la ua uatto) ini juga bagian dari pada upaya menegakkan larangan-larangan dalam agama oleh sebab itu tradisi ini juga berjalan seiring dengan agama dan tidak bisa dipisahkan. hukum cambuk (mihitta la ua uatto) ini adalah satu upaya untuk memberikan efek jera kepada pelanggar aturan adat dan juga merupakan simbolisasi adat istiadat di Negeri Iha-Ulupia, Kecamatan Huamual, Kabupaten Seram Bagian Barat dan menjadi warisan dari leluhur untuk generasi berikutnya. sebab itu hukum cambuk (mihitta la ua uatto) ini juga bagian dari pada tradisi atau budaya yang sudah melekat di dalam kehidupan masyarakat adat Negeri Iha-Ulupia tersebut. Hal ini sama halnya dengan apa yang disampaikan oleh Shills bahwa tradisi adalah segala sesuatu yang di salurkan dari masa lalu ke masa kini (Piotr Sztompka, 1981). dalam arti yang sempit tradisi berarti bagian-bagian warisan sosial, khusus yang tetap bertahan hingga kini dan masih kuat ikatannya dengan kehidupan di masa lalu. Jadi hukum cambuk ini merupakan salah satu bentuk budaya bagi masyarakat Negeri Iha kecamatan Huamual kabupaten Seram Bagian Barat. 


$\begin{array}{ll}\text { Volume } & : 7 \\ \text { Nomor } & : 3 \\ \text { Bulan } & : \text { Agustus } \\ \text { Tahun } & : 2021\end{array}$

\section{Pandangan Hak Asasi Manusia (HAM) Terhadap Pelaksanaan Hukum Cambuk (Mihitta La Ua Uatto) di Negeri Iha-Ulupia?}

Leon Duguit menempatkan solidaritas sosial sebagai dasar konstruksi teori tentang hukum, solidaritas dalam membangkitkan dua rasa yakni rasa keharusan sosial (sentiment de la sosialite) dan rasa keadilan (sentiment de la justice). Rasa keharusan sosial, tampil dalam wujud keyakinan akan perlunya pedoman-pedoman bersama yang sesuai dengan kebutuhan masyarakat. Sedangkan rasa keharusan keadilan, menunjuk pada kepekaan tentang cara membagi beban dan imbalan yang proporsional. dari kedua rasa keharusan inilah, hukum itu lahir. dan hukum itu adalah hukum karya social, hukum ini merupakan hukum fundamental masyarakat-hukum yang menguasai seluruh hidup bersama. la tidak dibuat tetapi muncul spontan dari pergulatan internal masyarakat. isinya, berupa kaidah-kaidah yang bermuatan nilai-nilai ekonomis dan moral yang dipandang hakiki dalam masyarakat karya (Munir Fuadi, 2007)

"Aturan hukum cambuk (mihitta la ua uatto) yang di terapkan di Negeri Iha-Ulupia sudah sejak dahulu kala sebelum adanya UU/hukum positif, tapi kalau pribadi saya bahwa sebagai kepala desa/raja dengan tegas saya katakan bahwa untuk melihat adanya hukum psoitif yang sudah berlaku di Indonesia seperti halnya UU HAM dan sebagainya, jika di katan melanggar aturan adat cambuk di Negeri Iha-Ulupia secara subtansi, tidak melanggar Hukum Positif, salah satunya HAM, karena memiliki landasan pada pasal 18B ayat (2) UUD 1945. dan KUHP benar tertulis mengenai perkara pidana di indonesia namun tidak mengsampingkan hukum adat yang di berlakukan pada wilayah tertentu, Kebanyakan presepsi masyarakat luar daerah, bahwa aturan cambuk yang di terapkan di Negeri Iha-Ulupia ini sudah melanggar aturan hukum nasioanl, saya pikir bahwa masyarakat IhaUlupia ini merupakan negeri adat, sudah jelas suatu adat di dalam wilaya masyarakat itu di akui oleh negara dan menghormati kesatuan-kesatuan masyarakat hukum adat, jadi kalau mau di hentikan karena melanggar aturan adat saya piker bahwa aturan ini tidak bisa di hentikan, tapi aturan ini tetap di pertahankan biasanya dari saniri rapat itu di tawarkan ke masyarakat apakah hukuman cambuk ini bisa di pertahankan atau di berhentikan, namun biasanya tanggapan atau jawaban dari masyarakat yaitu di pertahankan, karena sangat efektif untuk menjaga ketertiban masyarakat ini bisa terjamin, karena kita tau semua bahwa cikal bakal kejahatan kriminal di desa Iha ini dari minuman keras, jadi hukum cambuk negeri Iha itu yang menonjol hanya bagi orang yang minum khamar atau minuman keras."

Berdasarkan penjelasan di atas, dapat di analisa bahwa adapun hukum cambuk (mihitta la ua uatto) yang di terapkan di negeri iha ini bersumber pada salah satu sumber hukum yang berlaku yakni hukum adat, Konstitusi kita sebelum amandemen tidak secara tegas menunjukkan kepada kita pengakuan dan pemakaian istilah hukum adat. Namun bila ditelaah, maka dapat disimpulkan ada sesungguhnya rumusan-rumusan yang ada di dalamnya mengandung nilai luhur dan jiwa hukum adat. Pembukaan UUD 1945, yang memuat pandangan hidup Pancasila, hal ini mencerminkan kepribadian bangsa, yang hidup dalam nilai-nilai, pola pikir dan hukum adat. Pasal 29 ayat (1) Negara berdasarkan Ketuhanan Yang Maha Esa, Pasal 33 ayat (1) Perekonomian disusun sebagai usaha bersama berdasarkan azas kekeluargaan.

Aturan hukum cambuk (mihitta la ua uatto) di negeri iha ini masih bersumber pdari sumber hukum adat dalam undang-undang juga memberikan jaminan pengakuan dan penghormatan hukum adat bila memenuhi syarat: 1. Syarat Realitas, yaitu hukum adat masih hidup dan sesuai perkembangan masyarakat; 2. Syarat Idealitas, yaitu sesuai dengan prinsip negara kesatuan Republik Indonesia, dan keberlakuan diatur dalam undang-undang; Pasal 28 I ayat (3) UUD 1945 menegaskan bahwa "Identitas budaya dan hak masyarakat tradisional dihormati selaras dengan perkembangan zaman dan peradaban".

\section{Pembahasan}

Masyarakat Negeri Iha-Ulupia memeliki ciri khas sosial budaya tersendiri. masyarakat Negeri Iha-Ulupia, sangat berpegang teguh dengan nilai-nilai islam dijalankan secara bersama. karena didalam nilai adat, terdapat nilai-nilai islam yang tidak bisah dilepas pishkan satu sama lain. (Pattimahu, 2019) dalam suatu komunitas masyarakat adat, ternyata agama tidak menjadi satusatunya faktor dalam mempengaruhi pemikiran dan perilaku masyarakat. nilai-nilai adat lokal juga menjadi determinan dalam pembentukan dinamika pemikiran berikut perilakunya. fakta ini menjadi ciri umum masyarakat indonesia yang lebih bersifat monodualisitik, khususnya di maluku dalam relasi adat dan agama, dimana agama dan adat sama-sama memiliki posisi yang penting.

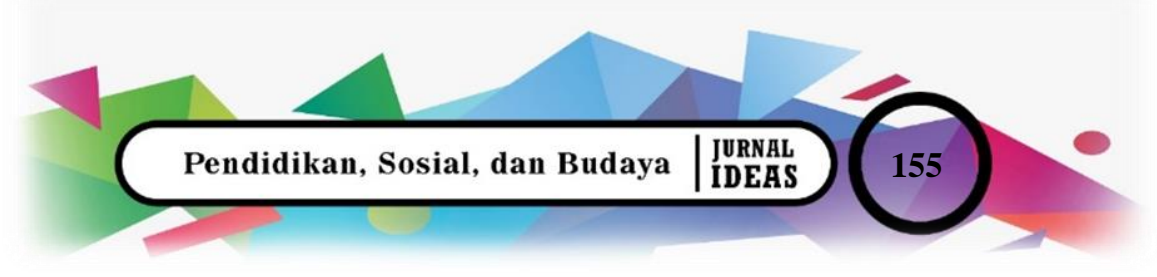


Negeri Iha-Ulupia memiliki salah satu tradisi adat yang bisa di katakan kuno dan unik yang mungkin untuk zaman yang sudah modern ini tidak di temukan lagi di bumi raja-raja di Maluku yaitu Hukum Cambuk (mihita la ua uatto) tradisi adat ini merupakan sebuah upaya para raja dan soa-soa yang ada di negeri iha dalam menyelesaikan persoalan-persoalan perilaku sosial yang menyimpang dimasyarakat negeri iha. Dalam pelaksanaanya dilibatkan Algojo (satgas) keamana negeri iha dengan cara mencambukki badan bagian belakang dengan menggunakan rotan jawa sebanyak 7 kali bagi pelaku penyimpangan sosial dan apabaila mengulanginya dengan kesalahan yang sama maka hukumannya bertambah menjadi 14 kali dan apabila masih mengulanginya lagi maka orang tersebut akan di usir dan di izinkan pulang jika sudah sampai 5 tahun di luar daerah. Proses tradisi adat hukum cambuk ini di pimpin oleh kepala Pemuda (Malakau) dan di eksekusi oleh Algojo (satuan tugas atau marinyo) Negeri Iha.

Hukum adat cambuk yang hidup di lingkungan masyarakat adat iha-ulupia merupakan hukum yang hidup (the living law), karena ia menjelmakan perasaan hidup yang nyata dari rakyat. sesuai dengan fitrahnya, hukum adat terus menerus tumbuh dan berkembang seperti masyarakat sendiri. dapat diketahui bahwa teori (the living law) adalah hukum yang hidup dan sedang aktual dalam suatu masyarakat, sehingga tidak membutuhkan upaya reaktualisasi lagi. (the living law) bukan sesuatu yang statis, tetapi terus berubah dari waktu ke waktu. (the living law) adalah hukum yang hidup di dalam masyarakat, bisa tertulis bisa juga tidak. Secara sosiologis, the living law senantiasa akan hidup terus dalam masyarakat. (the living law) merupakan aturan-aturan yang digunakan di dalam hubungan-hubungan kehidupan yang sedang berlangsung dan bersumber dari adat istiadat atau kebiasaan (Lilis Rasjidi, 2007).

Hukuman cambuk itu biasanya di lakukan bagi masyarakat yang melanggar aturan dan norma-norma yang telah di jadikan sebagai hukum tidak tertulis dan sanksi sosial bagi para pelanggarnya. biasanya seperti kasus mabuk yaitu mengkonsumsi minuman keras (sopi dan alkohol) seperti yang tengah di jual di masyarakat dan perjudian. biasanya yang sering di langgar yaitu pada kasus mabuk atau mengkonsumsi minuman keras (sopi dan alkohol). untuk tempat atau lokasi dalam tradisi adat hukum cambuk di lakukan di rumah kepala pemuda dan di saksikan oleh seluruh masyarakat negeri iha sebagai pelajaran untuk tidak mengulangi hal yang demikian.

Selain itu hukum cambuk (mihitta la ua uatto) ini tidak memandang buluh entah itu anak yang masih kecil katakanlah pelajar maupun orang dewasa hingga orang tua pun harus di kenakan hukuman ini karena bagi masyarakat di negeri iha mabuk atau meminum sopi dan minuman alkohol lainnya adalah satu hal yang membuat negeri iha menjadi kotor dalam artian banyak terjadi masalah atau bencana alam yang menimpa negeri iha sehingga para peminum sopi dan alkohol harus di hukum seberat beratnya karena dampaknya bukan hanya bagi dirinya dan keluarganya tetapi bagi siapa saja yang bearada dan mendiami negeri iha

Hukum cambuk (mihitta la ua uatto) sebenarnya jika disaksikan langsung oleh orang-orang yang belum pernah melihatnya maka ia akan merasa aneh bahkan takut untuk menyaksikan proses hukum cambuk tersebut sebab hukum cambuk ini di lakukan dengan cara memukul badan seseorang yang sudah di buka bajunya sehingga yang di lihat hanyalah kulit badannya dan di pukul dengan rotan jawa yang berukuran satu meter dengan panjang dan tebalnya $25 \mathrm{~cm}$. Sedemikian sehingga apabila mengenai badan seseorang langsung kulitnya pecah dan bahkan keluar percikan darah di bagian belakang orang yang dicambuk sehingga apabila ada orang baru yang ingin menyaksikan proses hukum cambuk ini bisa takut bahkan histeris karena sangat ekstrim dan badan orang yang dicambuk juga tidak di berikan berkat atau mantra-mantra yang biasanya diberikan agar kebal terhadap cambukkan rotan jawa tersebut. Jadi, dampak hukuman yang dirasakan oleh terhukum tersebut begitu sakit dan perih bahkan karena tidak kuat menahan cambukkan rotan jawa tersebut ada yang pinsan akibat terlalu sakit.

Idris Samal, 2021 mengatakan bahwa hukum cambuk (mihitta la ua uatt) itu adalah salah satu pemberian efek jera kepada masyarakata adat Iha-Ulupia yang melakukan pelanggaran, maka pelaku tersebut mendapat sanksi berupa cambukan sebanyak 7 kali”

Berdasrakan pembahasan yang peneliti dapat dari salah satu informan terkait hukum cambuk (mihitta la иа иatto) dapat di analisis bahwa hukum cambuk (mihitta la ua uatto) bahwasanya ini merupakan suatu bentuk upaya efek jera terhadap para pelanggar aturan yang telah ditetapkan di dalam Negeri Iha-Ulupia kecamatan Huamual Kabupaten Seram Bagian Barat. salah satu aturannya yaitu di larangan mengkonsumsi minuman keras. Esensi dari hukumam cambuk (mihitta la ua uatto) yang di terapkan di Negeri Iha-Ulupia merupakan suatu bentuk warisan leluhur kepada masyarakat Negeri iha-Ulupia dalam mengupayakan agar menjaga kesucin dalam negeri. sebgaimana di katakana oleh (hasan sahadily, 2002) bahwa tradisi biasa di katakan sebagai suatu 
kebiasaan masyarakat yang memiliki pijakan sejarah masa lampau dalam bidang adat, bahasa, tata kemasyarakatan, keyakinan, maupun proses penyerahan dan penerus pada generasi berikutnya.

Bapak pejabat Negeri Iha (Reza Latukaisupy, 2021) mengatakan bahwa selama hukuman cambuk di lakukan, sudah pasti ada laporan dari satuan tugas (satgas) dan apabila tersangka di tangkap dengan bukti-bukti yang/fatal baru bisa di cambuk, dan sebelum cambuk itu dilkukan ada sidang bersama, supaya ada pembicraan untuk menasehati par tersangka tersebut, supaya tersangak tidak mengulangi perbuatnnya lagi. Aturan ini sudah sejak dahulu, masyarakat juga sadari hal tersebut, dan masyarakat juga tahu bahwa aturan ini sudah diberikan tanggung jawab terhadap persoalan-persoalan tentang penerapan hukum adat cambuk tetap di berlakukan dengan satu kali kesalahan itu tujuh kali pukulan cambuk, kalu dua kali kesalahan empat belas kali pukulan cambuk, kalu tiga kali kesalahan yang sama dua puluh satu cambuk ples diasingkan dari dalam negeri."

Dari hasil pembahasan tersebut dapat dianalisis bahwa hukum cambuk berlaku di Negeri Iha-Ulupia masyarakat ingin memelihara nilai adat yang telah dilakukan di dalam negeri iha secara turun temurun. pelangaran-pelanggaran yang umumnya terjadi didalam masyarakat dapat ditekan dengan pemberlakuan hukum adat cambuk yang diselengarakan secara terbuka, prosesi mau jalan dan tidaknya tergantung adanya laporan dari Algojo/satuan tugas (satgas), dalam hal ini apabila kedapatan masyarakat yang mengkonsumsi minuman keras sudah pastinya di dilaporkan di berbagai staf pemerintah negeri untuk mencambuk pelaku tersebut. hal ini sebagaiman di kutip dalam (Hilman. H ,2004;7) Sanksi adalah salah satu aturan yang mengatur bagaimana pranata-pranata hukum mencampuri suatu masalah agar dapat memelihara suatu sistem sosial sehingga masyarakat hidup dalam sistem yang dibentuk secara tenang serta dengan cara-cara yang dapat diperhitungkan.

Zulkifli Selan, 2021 selaku kepala pemuda Iha-Ulupia mengatakan bahwa, kalau di lihat pada aturan hukum cambuk yang di terapkan sejak dahulu kala sebelum adanya UU/hukum positif, untuk melihat adanya hukum psoitif yang sudah berlaku di Indonesia seperti halnya UU HAM dan sebagainya, hukuman cambuk yang di terapkan di Negeri Iha-Ulupia secara subtansi, tidak melanggar HAM, karena memiliki landasan pada pasal 18B ayat (2) UUD 1945. KUHP benar tertulis mengenai perkara pidana di indonesia namun tidak mengsampingkan hukum adat yang di berlakukan pada wilayah tertentu.

Dari penjelasan di atas dapat di analisis bahwa adapun hukum cambuk yang di terapkan di negeri iha ini bersumber pada salah satu sumber hukum yang berlaku yakni hukum adat, Konstitusi kita sebelum amandemen tidak secara tegas menunjukkan kepada kita pengakuan dan pemakaian istilah hukum adat. Namun bila ditelaah, maka dapat disimpulkan ada sesungguhnya rumusan-rumusan yang ada di dalamnya mengandung nilai luhur dan jiwa hukum adat. Pembukaan UUD 1945, yang memuat pandangan hidup Pancasila, hal ini mencerminkan kepribadian bangsa, yang hidup dalam nilai-nilai, pola pikir dan hukum adat. Pasal 29 ayat (1) Negara berdasarkan Ketuhanan Yang Maha Esa, Pasal 33 ayat (1) Perekonomian disusun sebagai usaha bersama berdasarkan azas kekeluargaan.

Berdasarkan analisa di atas, maka dapat di simpulkan bahwa aturan hukum cambuk di Negeri Iha-Ulupia masih bersumber pada sumber hukum adat. dalam konsitusi juga sudah memberikan jaminan pengakuan dan penghormatan hukum adat bila memenuhi syarat: 1 . Syarat Realitas, yaitu hukum adat masih hidup dan sesuai perkembangan masyarakat; 2. Syarat Idealitas, yaitu sesuai dengan prinsip negara kesatuan Republik Indonesia, dan keberlakuan diatur dalam undang-undang; Pasal 28 I ayat (3) UUD 1945 menegaskan bahwa identitas budaya dan hak masyarakat tradisional dihormati selara dengan perkembangan zaman dan peradaban.

Dilihat pada Pasal 18 B ayat (2) dan Pasal 28 I ayat (3) pada prinsipnya mengandung perbedaan dimana Pasal 18 B ayat (2) termasuk dalam Bab VI tentang Pemerintahan Daerah sedangkan 28 I ayat (3) ada pada Bab XA tentang Hak Asasi Manusia. Lebih jelasnya bahwa Pasal 18 B ayat (2) merupakan penghormatan terhadap identitas budaya dan hak masyarakat tradisional (Rahardjo \& satjipto, 2009).

\section{Simpulan}

Berdasarkan analisa data yang telah dilakukan, berikut ini dikemukakan kesimpulan yaitu sebagai berikut. Pelaksanaan Hukum Cambuk (mihita la ua uatto) di Negeri Iha-Ulupia yakni dimulai dari pemberian kewenangan dalam menyelesaikan sengketa kepada satgas negeri dan pemuda untuk diadili, pelaksanaa hukum cambuk bertempat dikediaman kepala pemuda, alat cambuk yang digunakan yakni terbuat dari rutan jawa dengan diameter 2,5-3 cm dengan panjang kisaran 1.5 meter. Saat hukum cambuk dilaksanakan, tersangka sebelumnya disuruh untuk membuka bajunya apabila tersangka pria dan menghadap dinding rumah, tukang

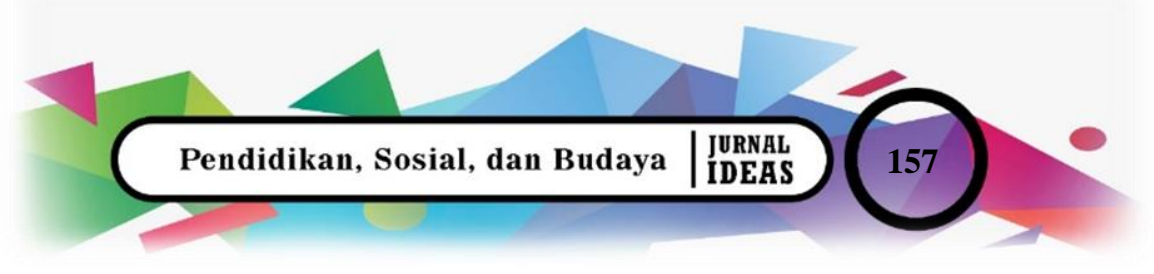


Volume : 7

Nomor : 3

Bulan : Agustus

Tahun : 2021

cambuk (marinyo) sebagai eksekutor berada di belakang dan agak menyamping dari badan tersangka dengan jarak kurang lebih 1,5 meter. pelaku yang terbukti meminum minuman keras akan dihukum dengan 7 kali cambukan, apabila masih melanggar dengan kasus yang sama maka akan dicambuk 14 kali dan dikucilkan dalam masyarakat negeri, dan apabila melanggar lagi maka akan di cambuk 21 kali dan diusir dari dalam negeri Iha. hukum cambuk yang di terapkan di negeri iha-ulupia itu merupakan simbolisasi dari pada adat istiadat yang su ada dari dolo agar memberikan efek jera untuk orang-orang yang langgar aturan adat. dilihat dari prespektif Hak Asasi Manusia bahwa hukuman cambuk yang di terapkan di Negeri Iha-Ulupia ini di laksanakan secara substansi tidak melanggar HAM karena memiliki landasan pada pasal 18 B ayat (2) UUD. Dan KUHP benar tertulis mengenai perkara pidana di Indonesia namun tidak mengsampingkan hukum adat yang berlakukan pada wilayah yang ada di Indonesia, dan hukum cambuk di negeri iha ini tidak bisa di batalkan atau di hentikan secara atau dalam bentuk apa, karena hukum adat itu pengauan masyarakat secara kolktif dan sudah do berlakukan banyak secara yuridis dan telah mendaptkan tempat landasan konstitusi sebagaimana di atur dalam UUD 1945. Kemudian secara regulasi dia merupakan sumber hukum yang masih berlaku diindonesia yang di akui secara tidak tertulis untuk mengatur ketertiban masyarakat

\section{Daftar Rujukan}

Creswell, J. (2016). Fungsi Kedua Pernyataan Kualitatif \& Desain Penelitian Memilih dI Antara Lima Pendekatan. In Design: Choosing Among Five Approaches (Vol. 3, Issue June).

H. Hilman Hadikusuma, (2004), Pengantar Antropolgi Hukum, Citra Aditya Bakti, Bandung.

Latupapua, F. E. (2009). IDENTITAS BUDAYA AMARIMA PEMERTAHANAN BAHASA HARUKU, DI PULAU HARUKU ,. Article, 8.

Lili Rasjidi \& Ira Thania Rajidi (2002) Pengantar Filsafat Hukum, Bandung : Mandar Maju.

Maladi, Y. (2010). Eksistensi Hukum Adat dalam Konstitusi Negara Pasca Amandemen. Mimbar Hukum, $22(3), 450$. https://doi.org/10.22146/jmh.16235

Merdiyatna. (2019). Jurnal Pendidikan Bahasa dan Sastra Indonesia. Jurnal Pendidikan Bahasa Dan Sastra Indonesia, 4(1).

Munir Fuadi (2007), Sosiologi Hukum Kontemporer, lnteraksi hukum dan Masyarakat, Citra Aditya Bakti, Bandung.

Nurdianzah, E. (2020). Akulturasi Budaya Dalam Dakwah Sultan Hadirin Di Desa Loram Kulon Kecamatan Jati Kabupaten Kudus. Jurnal Penelitian Sejarah Dan Budaya, 6(2), 276. https://doi.org/10.36424/jpsb.v6i2.200

OnaYulita, Khairul Anwar \& Dody Putra, M. I. (2021). Alkuturasi Budaya Pernikahan Minangkabau Dengan Transmigrasi Jawa Di Kabupaten Solok Selatan Sumatera Barat (p. 3).

Pattimahu, M. A. (2019). Dialektika Agama dan Budaya Dalam Ritual Hitirima Masyarakat Negeri Pelauw Maluku Tengah. Article, 3 .

Piotr Sztompka. (1981). Perubahan Sosial, Kasus Masyarakat Pascakomunis (p. 12).

Rahardj \& Satjipto (2009) Negara Hukum Yang Membahagiakan Rakyatnya, Yogyakarta: Genta Publishing.

Sumanto, D. (2018). Hukum Adat Di Indonesia Perspektif Sosiologi Dan Antropologi Hukum Islam. JURIS (Jurnal Ilmiah Syariah).

Sugiyono, Metode Penelitian Kuantitatif, Kualitatif dan R \& D, (Bandung: Alfabeta, 2014).

Tutuarima, Fricean, dkk. (2009). "Persekutuan Masyarakat Adat Amarima Hatuhaha sebagai Model Pluralitas Sosial" Laporan Penelitian Hibah Strategi Nasional Universitas Pattimura Ambon 